\title{
THE IMPACT ON LEADERSHIP OF THE VILLAGE GOVERNMENT, THE GOVERNMENT OFFICIAL'S COMPETENCE, MOTIVATION AND PARTICIPATION OF THE PEOPLE TOWARD EFFECTIVENESS OF THE EMPOWERMENT OF BUM DESA IN KLATEN REGENCY
}

\author{
Tyastuti Sri Lestari \\ Ph.D candidate \\ Satyagama University, Jakarta- Indonesia
}

Josy Adiwisastra

Professor of Public Policy Field of Government Science Pajajaran University, Bandung-Indonesia

Musa Hubeis

Professor of Public Policy field of Government Science Agricultural Institute, Bogor -Indonesia

\author{
Hariatia Ambiar \\ Senior Lecturer \\ Satyagama University
}

DOI: $10.31364 / S C I R J / v 8 . i 2.2020 . P 0220746$

http://dx.doi.org/10.31364/SCIRJ/v8.i2.2020.P0220746

\begin{abstract}
This study has a purpose to know the impact on leadership of the village government, the government official's competence, motivation and participation of the people toward effectiveness of the empowerment of BUM Desa in Klaten Regency, Central Java, Indonesia. The rapid growth of BUM Desa may still not meet the requirements of the establishment, the organizational structure, main duties and functions (tupoksi) and its accountability so that the management of BUM Desa is assumed less effective. This method of study uses a quantitative approach where the means for data collection is by conducting survey through questionnaires and field observation. In addition, the secondary data is obtained from the Agency for Rural Community Empowerment in Klaten Regency. This data is then analyzed statistically by using a multiple regression analysis. The study result shows that leadership, the government official's competence, motivation and participation of the people either partially or collectively have significant impact toward effectiveness of the empowerment of BUM Desa in Klaten Regency. Thus, to make the establishment of BUM Desa more effective, it needs an effort to improve a sense of leadership that can build a communication, review a business prospect, solve problems and become assertive in making decision; improve the government official's competence by the improvement of analytical thinking ability in managing the administration affairs; strengthen
\end{abstract}

the motivation to improve a cooperation with the business of BUM Desa in order to increase the welfare of people to obtain health and education facilities based on the result of empowerment of BUM Desa. Effectiveness of the empowerment of BUM Desa has a contribution in increasing its local-own source revenue.

Key Words: leadership, the government official's competence, motivation, participation of the people, the effectiveness of BUM Desa

\section{INTRODUCTION}

Klaten Regency consisting of 391 villages is called as the prospective regency and it already had 228 villages that have BUM Desa with various units of business development from tourism, handicraft and business economy to saving and loan. The existence of BUM Desa itself is in accordance with the program made by the central government namely to build Indonesia from the rural area by strengthening the villages, then a village government and its people need to implement such program in order to realize the improvement of village development and economy. One of the prioritized programs is the development of BUM Desa as a driving motor of people's economy.

The population of Klaten Regency has more than 1 million persons, thus it is really needed to concern for the 
people's welfare. The existence of BUM Desa in order to increase the people's welfare becomes the motivation of the village to establish BUM Desa. One of them is BUM Desa Tirta Mandiri of Ponggok Village, Sub-District of Polanharjo. The success of BUM Desa Tirta Mandiri even becomes a national pilot project in managing such BUM Desa. Within a year, BUM Desa Tirta Mandiri has achieved the revenue up to billions rupiah from the various units of its business being managed. The second ranking of BUM Desa is BUM Desa Gumregah of Gununggajah Village, Sub-District of Bayat that is quite successful in managing the village potency. BUM Desa Gumregah manages the tourism park of Watu Prau Bukit Cinta.BUM Desa Gumregah was established around early 2016. From such management of tourism-park of such Watu Prau, BUM Desa has an income more than Rp 50 million per month (Klaten.sorot.co).

Nevertheless, the established BUM Desa is often stagnant and may not have any yield yet from its business units. Based on the data from the Agency for Empowerment and the Village Government (Permades) of Klaten Regency, up to this present time, there have been 294 BUM Desa that have been established and in the Regulation of Governor of Central Java Number 18 of 2018 on Guidelines for the Development and Supervision of BUM Desa in Central Java Province, it needs a regulation to fill the non-existing regulation of the village government Number 4 of 2015 as a basis for the development and supervision in establishing, managing and performing activities of BUM Desa. The Governor Regulation has principles as follows: (1) Locally potency-based, (2) Participation of the people, (3) Empowerment of community stands up for the people and communal work (4) Democracy (5) Transparency and (6) Diversity and sustainability.

Based on the classification already conducted in April 2018, from those 294 BUM Desa in Klaten Regency, there are 7 (seven) BUM Desa that have criterions of well-developed meaning that these 7 (seven) BUM Desa have met the requirements in the classification. The remaining BUM Desa are categorized into these criterions: developed of 14 (fourteen), growing of 158 (one hundred and fifty eight) and non-developed of 115 (one hundred and fifteen) BUM Desa.

The points of classification on the progress of BUM Desa in Central Java Province referring to the Governor Regulation Number 18 of 2018 have these following parameters:

1. Institution

2. Rules/Legality: Regulations of BUM Desa

3. Business of BUM Desa

4. Administration, reporting and accountability

5. Capitalization and asset

6. The impact of BUM Desa toward people

\section{LITERATURE REVIEW}

The factors as the keys in supporting the health and sustainability of BUM Desa are leadership, managerial skills and good governance (KMT), where such leadership of the village government impacts on effectiveness of the empowerment of BUM Desa(Kamaroesid, 2016), as being failed or successful of BUM Desa really depends on the way that the Head of Village leads the village. Leadership of the Village Government as a political capacity in directing policies in form of regeneration by performing education and training as well as opening public spaces and political struggle access for the benefit of the people. Politics in this context are not in terms of struggle of power, but it is the reinforcement of knowledge and awareness on the rights, interests and power of the people and the people's organization as political representation of power in order to compete in making access to the arena and resources of village. The approach of assistance from the government official that has competence shall strengthen people's power and make a village system more democratic. A village system meant here is the authority of village, the organizing of the village government, as well as the planning and budgeting of village that all of them refer to the village development for people's welfare. The interest, theme of development, local assets and various factors are directed and bound into such village system. In other words, a village becomes a basis of having community, politics, government, democracy and development.

The establishment of BUM Desa is one of the strategic forms in the implementation of the Village Government. It may need various kinds of strategic interventions systematically and suistanably, mainly related to the development of institutional capacity and the government officials. Thus, it is hoped that an excellent local government official who can integrate and keep balance between its technical and non-technical job, between loyalty and integrity, between routines and creativity. Allan Trayer (dalam Murley, 1997, hal. 21) says that a competence is defined as a capability of a person to use his/her skills in order to produce the best service of performance. The government official's competences as the capacity of institutional process and bureaucracy are giving the best services and becoming a companion of village that should ensure that the Head of Village is a leader of the people and not a leader of parts of the groups, families, descendants, religions, certain tribes and so on. A leader of the people means a leader who is close to his/her people, protect, guard and serve his/her people.

A competent government official can create a culture of leadership that realizes the importance of legitimation in leading its village. Such legitimation is useful to optimize the performance of village in realizing the welfare of village people. The official also has duties to accompany the village by encouraging the leaders in that village to become a good model for his people, as well as being honest, clean, innovative and transformative.

Abraham H. Maslow has opinion that internal needs really influence human motivation in working. According to Siagian (2002, hal. 102), motivation is a driving power for a person to give optimum contribution for the success of the organization in achieving its purpose.

Riwu Kaho (dalam Sumaryadi, 2010, hal. 52) say that the conception of participation is related directly with a democracy idea where basic principles of democracy are "from, by and for the people". The participation takes form in various patterns or activities. The participation that always related to the activities of people, government and private sectors is a kind of participation in the development. Mubyarto (dalam Sumaryadi, 2010, hal. 49), explains the form of participation of the people in the development as follows:

a. The activity of community development target, namely the improvement of condition and increase of the living standards of the people, the uprising of participation of 
the people, and the growth of people's ability to grow independently and may not stand alone, but it is managed to connect each other, so that the three of them can be deemed as one package of business.

b. The increase of the living standards of the people is managed as an effort of the fulfillment of need and the improvement of community self-reliance as well as the effort to trigger out the participation of the people.

It is expressed by Supriyono (2000, hal. 29) that effectiveness is a relation between the output of a responsibility center and the target that should be achieved. The bigger contribution of the output produced toward target achievement, such unit can be said effective. Thus, effectiveness is an act that has meaning on the occurrence of the desired effect or result and focuses on its result or effect in achiecing the purpose. Effectiveness is a description of the level of success or excellence in achieving target that has been determined and it is bound among various values. In this case, Atmosoeprapto (2002, hal. 139) states that effectiveness is doing the right thing, meanwhile efficiency is doing the thing rightly or effectiveness is how far we achieve a target and efficiency means how we mix all resources accurately. Based on the conception of effectivess already explained, it seems that being efficient but not effective means using resources (input), but it would not achieve the target. On the contrary, being effective but not efficient means in achieving target, it uses over resources or commonly said as high economic cost. The review on the effectivess refers to two interests, either theoretically and practically. It means that there are comprehensive and detailed accuracies from the efficiency and goodness to obtain input on productivity. Effectiveness is a condition that impacts on impressive thing, efficacy, business success, acts or the prevailing thing.

With regard to the Management of Human Resources, Maier (2002, hal. 34) defines effectiveness as a level/limit of which the functions of human resources support the success of the implementation of ideas and plans as wellas long-term strategy of the organization. This definitions relates it with the result achieved for each strategy and human resources problems.

\section{HYPOTHESIS OF STUDY}

Based on the observation that has been submitted before, there are some hypotheses related to effectiveness of the empowerment of BUM Desa in Klaten Regency:

H1: There are positive and significant relations between leadership of the Village Government and effectiveness of the empowerment of BUM Desa in Klaten Regency.

$\mathrm{H} 2$ : There are positive and significant relations between the government official's competence and effectiveness of the empowerment of BUM Desa in Klaten Regency

H3: There are positive and significant relations between motivation and effectiveness of the empowerment of BUM Desa in Klaten Regency

H4: There are positive and significant relations between participation of the people and effectiveness of the empowerment of BUM Desa in Klaten Regency

H5: There are positive and significant relations collectively between leadership of the Village Government, the government official's competence, motivation and participation of the people and effectiveness of the empowerment of BUM Desa in Klaten Regency.

\section{METHOD OF STUDY}

Method of study is a way of thinking and acting that is well-prepared in order to achieve the purpose of study, namely to find, develop or review the truth of knowledge scientifically or for hypothesis test of a study (Husaini Usman, 1992:46). The method used in this study is a quantitative method by using statistic calculation in hypothesis test purpose.

Designs of study are all necessary processes in planning and implementation of the study. Designs of study are comprehensive planning of study that relate to all components and steps of studies by considering the ethics of study, study resources and obsctacles. According to its type, this study is an explanatory research to test a hypothesis that states a cause and effect relation between two variables or more. In this study, a cause and effect relation should seem so real.

This study has purpose to know total impact of independent variables toward dependent variables, either partially or collectively. The variables of this study consist of 4 (four) independent variables and 1 (one) dependent variable. The independent variables are leadership of the Village Government $\left(\mathrm{X}_{1}\right)$, the government official's competence $\left(\mathrm{X}_{2}\right)$, motivation $\left(\mathrm{X}_{3}\right)$, participation of the people $\left(\mathrm{X}_{4}\right)$ and the dependent variable is the empowerment of Village-owned Business Entity/BUM Desa (Y).

$$
\hat{Y}=a+b_{1} X_{1}+b_{2} X_{2}+b_{3} X_{3}+b_{4} X_{4}
$$

Where $Y=$ Effectiveness of the empowerment of BUM Desa

$$
\begin{array}{ll}
\mathrm{X}_{1} & =\text { Leadership of the Village Government } \\
\mathrm{X}_{2} & =\text { The government official's competence } \\
\mathrm{X}_{3} & =\text { Motivation } \\
\mathrm{X}_{4} & =\text { Participation of the people } \\
\mathrm{a} & =\text { intercept } \\
\mathrm{b} 1 \ldots \mathrm{b} 4 & =\text { coefisient }
\end{array}
$$

\section{RESULT AND DISCUSSION}

\section{Validity and Reliability Tests}

Validity test is conducted with a purpose to measure its data reliability. A measuring instrument is valid if it has reliability toward things that should be measured. Based on the calculation of statistic result for each variable of 10 items of instruments (questionnaire) with 164 sample respondents (n $=164$ ), and its significance level of $\alpha=0,05$, it obtains that the value of $\mathrm{r}_{-}{ }_{\text {count }}$ is higher than $\mathrm{r}_{\text {-table }}$, so that it can be stated that all items of statements in the questionnaire of this study have been valid/legitimate.

A test can be said reliable, but it is not certainly valid, but then a test cannot be said valid if it is not reliable. It means that a consistency is the conditions that should be met for a validity of instrument. Reliability test is used to know how far a measuring instrument can be trusted or can be relied and it remains consistent if it is made two times of measurement or more on the same group with the same measuring instrument. The result of reliability test shows that all coefficient values of reliability or Alpha Cronbach of each variable of study has the value higher than 0,700 or Alpha Cronbach is higher than standard Alpha, so that it can be said that all items of statements are stated reliable as data collection instrument.

\section{Normality and Linearity Tests}


Normality test is used to know whether data has normal distribution or not. To count a normality test of data in this study, it is used Kolmogorov Smirnov Test. If the value of Kolmogorov Smirnov is higher than 0,05, then such data has normal distribution. Based on the result of calculation of normality test of data, it can be known that all values of Sig of each variable are higher than 0,05 , so that such data is stated as having a normal distribution of data.

Linearity test has a purpose to know whether two or more variables have a significant linear relation or not. Linearity test is used as a precondition in a linear regression analysis. The analysis instrument used is F-test assuming that $\mathrm{F}_{\text {-count }}$ is smaller than $\mathrm{F}_{\text {-table, }}$, then it has a linear relation between independent variables and dependent variables.The analysis result indicates the value of $\mathrm{F}_{\text {-count }}$ is smaller than $\mathrm{F}$ table, it has a linear relation between independent variables and dependent variables.

\section{Assumption Test of Classic Deviation}

Multi-Colinearity Test is used to know whether there is a correlation or collinearity between one independent variable to another. The result of Multi-Colinearity Test can be seen from the value of Tolerance Value and Variance Inflation Factor (VIF) on condition that Tolerance Value is higher than 0,01 and the value of VIF is less than 10 .

\section{Hypothesis Test}

By using a statistic program of SPSS version 23, it obtains that the calculation result of t-test and f-test for the test toward five (5) hypotheses that have been shown in Table 1 and Table 2. From those tables, it can be known that there are 4 (four) independent variables that have positive and significant impacts either partially or collectively toward dependent variables. Those 4 (four) independent variables are leadership of the Village Government $\left(\mathrm{X}_{1}\right)$, the government official's competence $\left(\mathrm{X}_{2}\right)$, motivation $\left(\mathrm{X}_{3}\right)$ and participation of the people $\left(\mathrm{X}_{4}\right)$, and the dependent variable is effectiveness of the empowerment of BUM Desa (Y). Significant impacts of the variables of leadership of the Village Government, the government official's competence, motivation and participation of the people toward effectiveness of the empowerment of BUM Desa can be seen from t-value namely for partial impact and f-value for collective impact.

\section{Table 1}

Simple Linear Regression Analysis

\begin{tabular}{|l|c|c|c|}
\hline \multirow{2}{*}{ Independent Variables } & \multicolumn{2}{|c|}{ T Test } & \multirow{2}{*}{ Remark } \\
\cline { 2 - 3 } & t-count & t-table & \\
\hline $\begin{array}{l}\text { Leadership of the Village } \\
\text { Government }\left(\mathrm{X}_{1}\right)\end{array}$ & 24.212 & 1.654 & Significant \\
\hline $\begin{array}{l}\text { The government official's } \\
\text { competence }\left(\mathrm{X}_{2}\right)\end{array}$ & 23.184 & 1.654 & Significant \\
\hline Motivation $\left(\mathrm{X}_{3}\right)$ & 24.238 & 1.654 & Significant \\
\hline $\begin{array}{l}\text { Participation of the people } \\
\left(\mathrm{X}_{4}\right)\end{array}$ & 18.483 & 1.654 & Significant \\
\hline Effectiveness of the empowerment of BUM Desa (Y) \\
\hline
\end{tabular}

Source: The output of SPSS 23

Based on the result of research data processing, it obtains that the value of t-count is higher than t-table with DF (158) of 1.654 and the value of Sig. 000 meaning that t-count is higher than $\mathrm{t}$-table, then $\mathrm{H}_{0}$ is rejected and $\mathrm{Ha}$ is accepted. It shows that leadership of the Village Government, the government official's competence, motivation, and participation of the people partially impact toward effectiveness of the empowerment of BUM Desa and it shows that the hypothesis is proven.

Table 2

Multiple Linear Regression Analysis

\begin{tabular}{|c|c|c|c|}
\hline \multirow[t]{2}{*}{ Independent Variables } & \multicolumn{2}{|c|}{ F-test } & \multirow[t]{2}{*}{ Remark } \\
\hline & f-count & $\mathbf{f}_{\text {table }}$ & \\
\hline Leadership of $\left(\mathrm{X}_{1}\right)$ & \multirow{4}{*}{$\begin{array}{c}146.7 \\
71\end{array}$} & \multirow{4}{*}{2.29} & \multirow{4}{*}{ Significant } \\
\hline $\begin{array}{l}\text { The government official's } \\
\text { competence }\left(\mathrm{X}_{2}\right)\end{array}$ & & & \\
\hline Motivation $\left(\mathrm{X}_{3}\right)$ & & & \\
\hline $\begin{array}{l}\text { Participation of the people } \\
\left(\mathrm{X}_{4}\right)\end{array}$ & & & \\
\hline
\end{tabular}

Source: The output of SPSS 23.

Based on the table 2 above, it is obtained that the value of f-count is 146.771 and the value of f-table of DF $(5 ; 158)$ is 2.29 with the value of Sig. 000 meaning that f-count is higher than f-table, then $\mathrm{H}_{0}$ is rejected and $\mathrm{H}_{\mathrm{a}}$ is accepted. It shows that the variables of leadership of the Village Government, the government official's competence, motivation, and participation of the people collectively have impact toward effectiveness of the empowerment of BUM Desa and the hypothesis is proven.

\section{Correlation Analysis}

Based on the result of research data processing, it is obtained that the coefficient value of determination or $\mathrm{R}^{2}$ for the government official's competence variable is 0.811 . It shows that $81.1 \%$ of the variable of effectiveness of the empowerment of BUM Desa is caused by the variable of the government official's competence meanwhile the remaining $18.9 \%$ is caused by other variables. For other independent variables, its determination coefficient value can be seen in this following Table 3:

\section{Table 3}

\section{Linear Regression Equation}

Based on the result of linear regression analysis, it

\begin{tabular}{|c|c|c|c|c|}
\hline Model & $\mathrm{R}$ & $\mathrm{R}$ Square & $\begin{array}{c}\text { Adjusted } \mathrm{R} \\
\text { Square }\end{array}$ & $\begin{array}{c}\text { Std. Error of the } \\
\text { Estimate }\end{array}$ \\
\hline $\mathrm{X} 1$ & $.911^{\mathrm{a}}$ & .830 & .828 & .14099 \\
\hline $\mathrm{X} 2$ & $.901^{\mathrm{a}}$ & .811 & .809 & .14845 \\
\hline $\mathrm{X} 3$ & $.919^{\mathrm{a}}$ & .844 & .842 & .13491 \\
\hline $\mathrm{X} 4$ & $.919^{\mathrm{a}}$ & .845 & .842 & .13512 \\
\hline
\end{tabular}

obtains the value of simple linear regression equation presented in this following Table 4:

Table 4

Simple Linear Regression Equation

\begin{tabular}{|l|c|}
\hline \multicolumn{1}{|c|}{ Independent Variables } & $\begin{array}{c}\text { Linear Regression } \\
\text { Equation }\end{array}$ \\
\hline Leadership of $\left(\mathrm{X}_{1}\right)$ & $\hat{\mathrm{Y}}=2,520+0,426 \mathrm{X} 1$ \\
\hline The government official's competence $\left(\mathrm{X}_{2}\right)$ & $\hat{\mathrm{Y}}=2,60+0,415 \mathrm{X}_{2}$ \\
\hline Motivation $\left(\mathrm{X}_{3}\right)$ & $\hat{\mathrm{Y}}=2,303+0,481 \mathrm{X}_{3}$ \\
\hline Participation of the people $\left(\mathrm{X}_{4}\right)$ & $\hat{\mathrm{Y}}=3,612+0,192 \mathrm{X}_{4}$ \\
\hline
\end{tabular}

Source: The output of SPSS 23

This following Table 5 indicates multiple regression analysis result by producing an equation of multiple linear regressions as follows: 


$$
\begin{aligned}
& \hat{Y}=0.511+0.033 X_{1}+0.241 X_{2}+0.295 X_{3}+ \\
& 0.321 X_{4}
\end{aligned}
$$

The equation of multiple linear regressions above has these following meanings:

- That every increase of 1 point of the variable of leadership of the village government impacts on the increase of a coefficient value of the variable of leadership of the village government of 0,31 assuming that the variables of the government official's competence, motivation and participation of the people are constant.

That every increase of 1 point of the variable of the government official's competence impacts on the increase of a coefficient value of the variable of the government official's competence of 0,097 assuming that the variables of leadership, motivation and participation of the people are constant.

Table 5

\begin{tabular}{|c|c|c|c|c|c|c|c|}
\hline \multirow[b]{2}{*}{ Model } & \multicolumn{2}{|c|}{$\begin{array}{c}\text { Unstandardized } \\
\text { Coefficients } \\
\end{array}$} & \multirow{2}{*}{$\begin{array}{c}\text { Standardized } \\
\text { Coefficients }\end{array}$} & \multirow[b]{2}{*}{$\mathrm{T}$} & \multirow[b]{2}{*}{ Sig. } & \multicolumn{2}{|c|}{ Collinearity Statistics } \\
\hline & B & $\begin{array}{c}\text { Std. } \\
\text { Error }\end{array}$ & & & & Tolerance & VIF \\
\hline 1 (Constant & .511 & .128 & & 4.009 & .000 & & \\
\hline $\mathrm{X}_{1}$ & .033 & .030 & .032 & 1.087 & .278 & .633 & 1.580 \\
\hline $\mathrm{X}_{2}$ & .241 & .038 & .207 & 6.266 & .000 & .514 & 1.946 \\
\hline $\mathrm{X}_{3}$ & .295 & .038 & .261 & 7.716 & .000 & .490 & 2.041 \\
\hline $\mathrm{X}_{4}$ & .321 & .026 & .356 & 12.31 & .000 & .670 & 1.494 \\
\hline
\end{tabular}
Multiple Linear Regression Analysis

Source: The output of SPSS 23

That every increase of 1 point of the variable of motivation impacts on a coefficient value of variable of motivation of 0,338 assuming that the variables of leadership, the government official's competence and participation of the people are constant.

- That every increase of 1 point of the variable of participation of the people impacts on the increase of a coefficient value of variable of participation of the people of 0,056 assuming that the variables of leadership, the government official's competence and motivation are constant.

\section{The Implication of Study}

All parameters of classification appraisal of the development of BUM Desa are mainly related to the role of leadership of the Village Government. But then, there are still 115 BUM Desa that have non-developed criterion. BUM Desa has a non-developed criterion within a range of evaluation level between 1 and 2 meaning that, for an institutional parameter of BUM Desa in its establishment: (1) without any review and may not complete the documents yet, (2) its organizational structure is not yet complete, (3) the management determined in the Decree (SK) but not yet conduct any activities, (4) main duties and functions (Tupoksi) are not performed correctly. The ability of a leader in building a communication is instrumental on the determination of formulating team and business review process. The ability of a leader in solving problem and making decision expressly is required while conducting a meeting in the village and encouraging the team to provide complete supporting documents.
BUM Desa has a classification of approximately 273 BUM Desa under the criterion of Growing and NonDeveloped BUM Desa. It indicates that such BUM Desa still meet the value level from 1 to 3 . The indicators related to the government official's competence toward effectiveness of the empowerment of such BUM Desa not met yet are the Administration, Reporting and Accountability. On the value level of 1 to 3 , the administrative and bookkeeping management that are adequate, order and accountable are the competencies that should be owned by government village officials recorded in the organizational structure of BUM Desa.

The acquisition of evaluation result for the classification of BUM Desa is really aligned with a statement that a leader giving the training as an effort of motivation indicates the progress and trust of the people toward BUM Desa. But it doesn't mean that the rapid growth of BUM Desa in Klaten Regency triggers out a prospect for the villagers, but it is a concern that is necessarily controlled and monitored in its implementation. As in the parameter of the Impact of BUM Desa toward People related to the motivation of village toward effectiveness of the empowerment of BUM Desa, it may not meet the provision yet for people's welfare, but it may harm the existing business in the community.

And based on the result of evaluation of classification of BUM Desa, it still needs participation of the people for the parameters of Business of BUM Desa and Capitalization/Asset. Upon participation of the people, the business of BUM Desa can be marketed locally to go-public, both nationally and internationally. It can be performed with a communication between people and leaders of the village government, but it can be a threat if such business is monopolized by a group of villagers directly or the leaders of village government. People's respond toward the statement is good where a well-built communication has become the evidence that the people trust on the business of the village government to fight for people's welfare, so that the business unit, market and business sustainability of BUM Desa shall be joint responsibility of the people and village government.

Meanwhile data obtained from Dispermasdes is then processed again by the researcher and it is collected in this following table, thus it is found that the average point of value of classification on the evaluation of BUM Desa in Klaten Regency as follows:

The average classification of BUM Desa in such Klaten Regency has the value between 1 and 2, and it has these following definitions:

1. The institution: Main duties and functions are not yet optimum.

2. Rules/Legality: Regulations of BUM Desa: it only has Village Regulations and Decrees of Head of the Village.

3. Business of BUM Desa: Business products of BUM Desa are still marketed locally in the village.

4. Administration, reporting and accountability: Bookkeeping is not yet conducted.

5. Capitalization and Asset: total assets are less than 200 millions.

6. The impact on BUM Desa toward people: BUM Desa may not give contribution for local-own source revenue.

\section{CONCLUDING REMARKS}

Based on the result of such findings, the effectiveness of 
the empowerment of BUM Desa in Klaten Regency shall influence the economic development of the village because its local-own source of revenue is not yet optimum. But it can positively become a model for the regencies nearby Klaten to increase the effectiveness of each BUM Desa.

Subsequently, leadership of the Village Government, the government official's competence, motivation and participation of the people toward effectiveness of the empowerment of BUM Desa, should be directed toward the effort of improving the economy, opening job opportunity and an even distribution of economy as well as increasing people's income and local-own source of revenue, namely through:

1. Leadership of the Village Government

a. Have a visionary leader that can direct BUM Desa into growing, advancing and suistable BUM Desa.

b. Supervision, development and control of the advisors, supervisors and operational executives of BUM Desa in conducting its main duties and functions.

c. Work program supervision that should be performed.

d. Supervision of the legality of BUM Desa, either village regulations, the decress of Head of the Village, Articles of Association/By-Law, Standard Operating Procedures (SOP) and a legal entity of business unit.

e. Support fully in the selection of business of BUM Desa which is village potency-based.

2. The government official's competence:

a. Give guidance to the management that has been determined with the decree of Head of the Village in order to implement the activities according to its job descriptions.

b. Give technical guidance and trainings for the management of administration and bookkeeping to be order and accountable.

c. Give guidance and counseling on the making of financial statement and information technology/computer-based activities.

3. Motivation

a. Motivate BUM Desa in improving its business product to be go-public at national and international level.

b. Motivate the leaders of village government that the establishment of BUM Desa is to improve the economy of people and may not close the existing business in the community.

c. Motivate BUM Desa in improving free facilities of health and education for the people.

4. Participation of the people:

a. Being active in the village meeting and review the business in BUM Desa.

b. Take a role in using the products of BUM Desa and make an investment to increase capital.

c. Cooperate with BUM Desa for business development purpose. d. Assist to explore and support the village potency to improve the business of BUM Desa.

e. Being active in the forum of BUM Desa in Klaten Regency and give positive information together in order to improve BUM Desa and the supply of job opportunity.

5. Effectiveness of the empowerment of BUM Desa:

a. BUM Desa as one of the agents of change other than agricultural sector because of the organized status of BUM Desa.

b. BUM Desa effectively gives the supply of job opportunity and increase the purchasing power of people and services to the people.

c. BUM Desa makes a cooperation among villages and gives its profit of business.

d. BUM Desa has various units of business and contributes in increasing its local-own source of revenue.

\section{REFERENCES}

[1] Assidddiqie, J. (2009) Kelembagaan Pemerintahan Menurut Konstitusi RI: Orasi Ilmiah. Jakarta: STIAMI

[2] Atmosoeprapto, K. (2002) Menuju SDM berdaya dengan kepemimpinan efektif dan manajemen efisien. Jakarta: PT. Elex Media Komputindo.

[3] Badan Pusat Statistik (2018) Hasil Pendataan Potensi Desa (Podes) 2018, Badan Pusat Statistik. Tersedia pada:

https://www.bps.go.id/pressrelease/2018/12/10/1536/has il-pendataan-potensi-desa--podes--2018.html (Diakses: 19 Juni 2019).

[4] Dwipayana, A. G. A. dan Eko, S. (ed.) (2003) Membangun Good Governance di Desa. Yogyakarta: IRE Press.Dwiyanto. A., 2008. Mewujudkan Good Government Melalui Pelayanan Publik: Cetakan Revisi 3. Yogyakarta: Gajah Mada University Press.

[5] Handayani, S., Suryono, A. dan Soeaidy, M. S. (2015) "Implementasi Kebijakan Kerjasama Desa melalui BKAD," JISIP: Jurnal Ilmu Sosial dan Ilmu Politik, 4(1), hal. 20-25. Tersedia pada: https://publikasi.unitri.ac.id/index.php/fisip/article/view/ 82.

[6] Irawan, N. (2017) Tata Kelola Pemerintahan Desa Era UU Desa. Jakarta: Yayasan Pustaka Obor Indonesia.

[7] Kamaroesid, H. (2016) Tata Cara Pendirian Dan Pengelolaan Badan Usaha Milik Desa. Jakarta: Mitra Wacana Media.

[8] Kerlinger, F. N. (1995) Asas-asas penelitian behavioral. 3 ed. Diedit oleh H. J. Koesoemanto. Diterjemahkan oleh L. R. Simatupang. Yogyakarta: Gadjah Mada University Press.

[9] Meier, D. (2002) The Accelerated Learning Handbook: Panduan Kreatif dan Efektif Merancang Program Pendidikan dan Pelatihan. Bandung: PT Mizan Pustaka.

[10] Murley, P. (ed.) (1997) Gower Handbook of Customer Service. Gower Publishing Limited.

[11] P.Siagian, S. (2002) Kiat meningkatkan Produktivitas Kerja. Jakarta: Bumi Aksara. 
[12] Sidik, F. (2015) "Menggali Potensi Lokal Mewujudkan Kemandirian Desa," JKAP (Jurnal Kebijakan dan Administrasi Publik), 19(2), hal. 115-131. Tersedia pada: https://journal.ugm.ac.id/jkap/article/view/7962.

[13] Sitepu, R. (2018) Analisis Proses Pembentukan dan Pengelolaan Badan Usaha Milik Desa (BUMDes) di Kecamatan Wampu Kabupaten Langkat. Universitas
Sumatera Utara. Tersedia pada: http://repositori.usu.ac.id/handle/123456789/8174.

[14] Sumaryadi, I. N. (2010) Sosiologi pemerintahan. Bogor: Ghalia Indonesia.

[15] Supriatna, T. (2015) Birokrasi dan Pemerintahan Daerah. Jakarta: PT Nagakusuma Media Kreatif.

[16] Supriyono, R. A. (2000) Sistem Pengendalian Manajemen. Yogyakarta: BPFE. 